\title{
Pneumopericardium, pneumomediastinum, pneumoretroperitoneum and surgical emphysema secondary to a duodenal perforation post- endoscopic retrograde cholangiopancreatography
}

Joshua Paul Harvey

Department of General Surgery, Medway Maritime Hospital, Gillingham, Kent, UK

\section{Correspondence to} Dr Joshua Paul Harvey, harveyjoshua90@gmail.com

Accepted 31 October 2015
CrossMark

To cite: Harvey JP. BMJ Case Rep Published online: [please include Day Month Year] doi:10.1136/bcr-2015209920

\section{DESCRIPTION}

A 46-year-old woman presented with severe upper abdominal pain and vomiting $12 \mathrm{~h}$ post-endoscopic retrograde cholangiopancreatography (ERCP) and sphincterotomy for choledocholithiasis. The patient also described a sensation of 'crackling in the neck' on head rotation. On examination, the patient was stable and afebrile, and had pain in the right hypochondriac region. She had subcutaneous crepitations in the right side of the neck and chest. Blood results showed white cell count $15.5 \times 10^{9} / \mathrm{L}, \mathrm{C}$ reactive protein $13.7 \mathrm{mg} / \mathrm{L}$, amylase $55 \mathrm{IU} / \mathrm{L}$, alanine transaminase $46 \mathrm{IU} / \mathrm{L}$ and alkaline phosphatase 300 IU/L; all other blood tests were normal.

An erect chest radiograph demonstrated a pneumopericardium, pneumomediastinum and surgical emphysema in the root of the neck (figure 1). An abdominal radiograph showed a large amount of retroperitoneal free air in the upper abdomen and surrounding the kidney-suggesting a duodenal perforation (figure 2). These findings were not present on the preprocedure film (figure 3 ).

The ERCP, performed by an experienced endoscopist, had been without apparent difficulty. During the procedure, a stone was identified as obstructing the distal common bile duct (figure 4). A sphincterotomy was performed and a biliary stent placed (figure 5).

The patient was managed conservatively with a nasogastric tube, intravenous fluids and antibiotics.

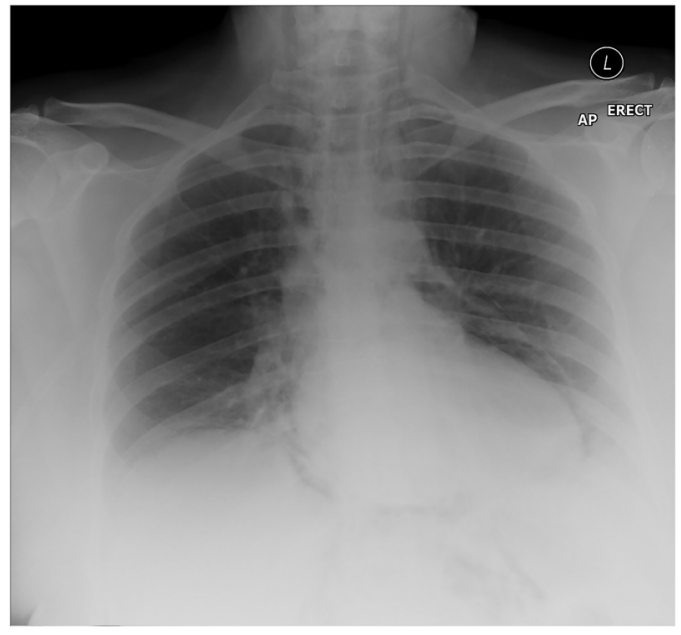

Figure 1 Abdominal radiograph demonstrating a large amount of retroperitoneal air, in particular, surrounding the kidneys.

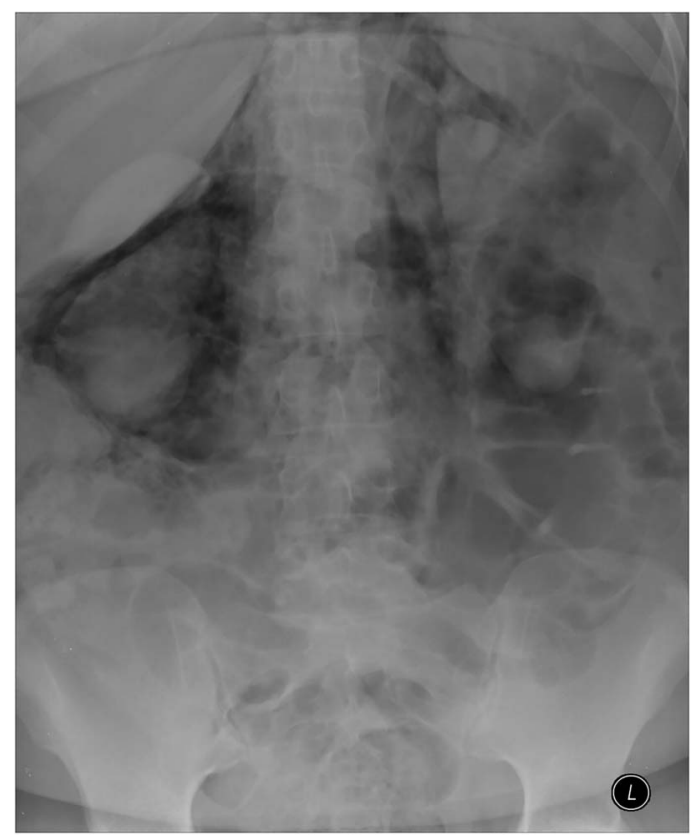

Figure 2 Chest radiograph demonstrating extension of the retroperitoneal air, which appears similar to a pneumopericardium. There is evidence of surgical emphysema in the root of the neck, which explains the 'crackling in the neck'.

She made a full recovery and was discharged 4 days later. A repeat chest radiograph on discharge showed reabsorption of the free air (figure 6).

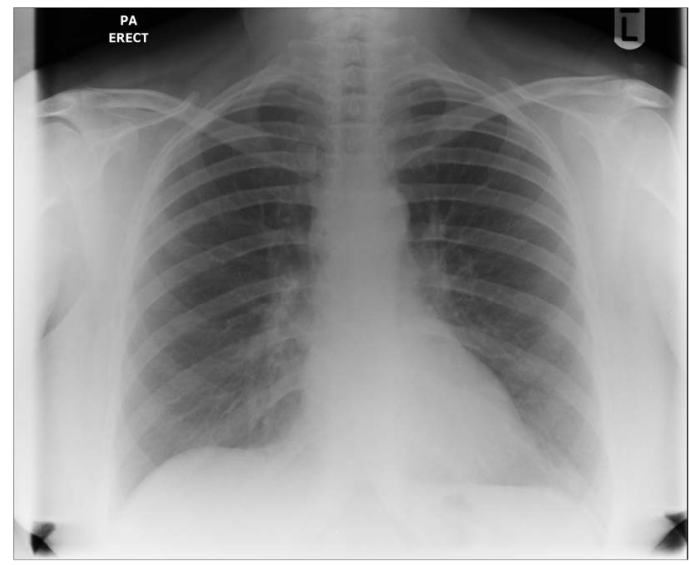

Figure 3 Repeat chest radiograph demonstrating reabsorption of the free air. 


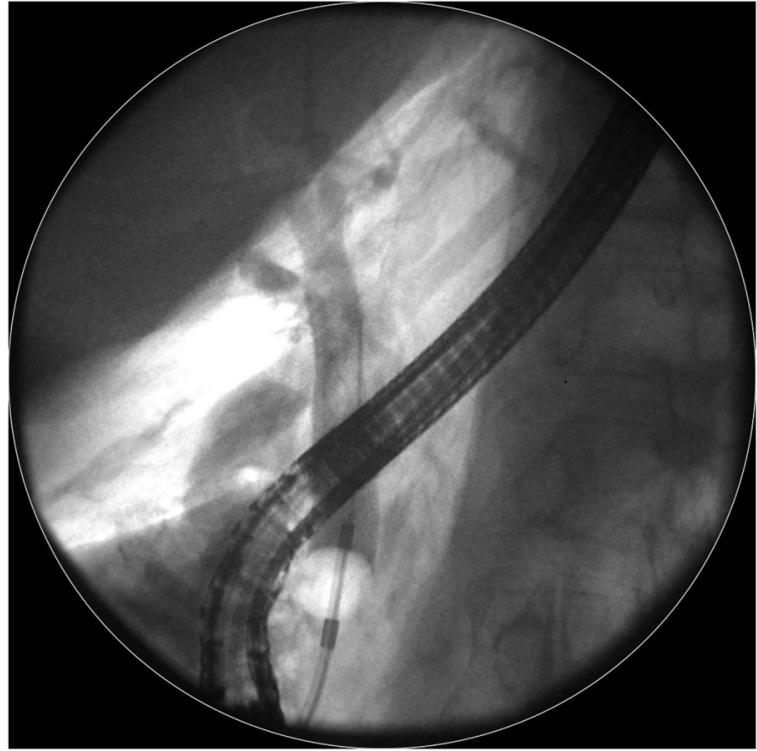

Figure 4 Fluoroscopy image demonstrating successful cannulation of the common bile duct stricture after sphincterotomy.

The incidence of perforation post-ERCP has been investigated by Howard et al, who performed a retrospective analysis of 6040 ERCPs. The group demonstrated that, of the 2874 patients $(48 \%)$ who had a sphincterotomy, 40 patients $(0.6 \%)$ went on to develop perforation. ${ }^{1}$ The group also reported an overall ERCP complication and mortality rate of $8.2 \%$ and $1.3 \%$, respectively.

Patients with a duodenal perforation often present with abdominal pain and vomiting, which mimics the more common complications of acute pancreatitis. ${ }^{2}$ Serum amylase and

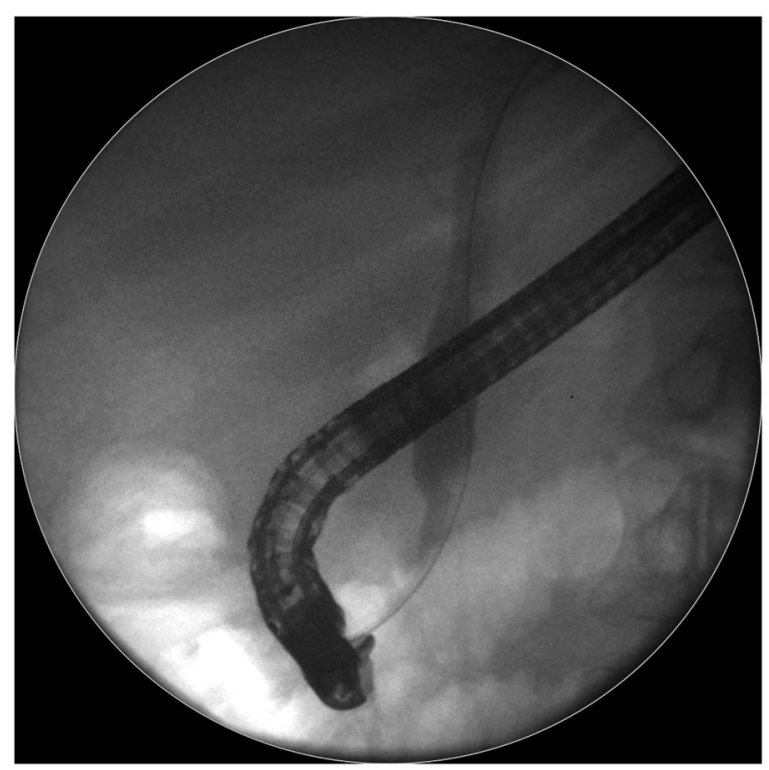

Figure 5 Fluoroscopy image demonstrating successful cannulation of the common bile duct stricture after sphincterotomy.

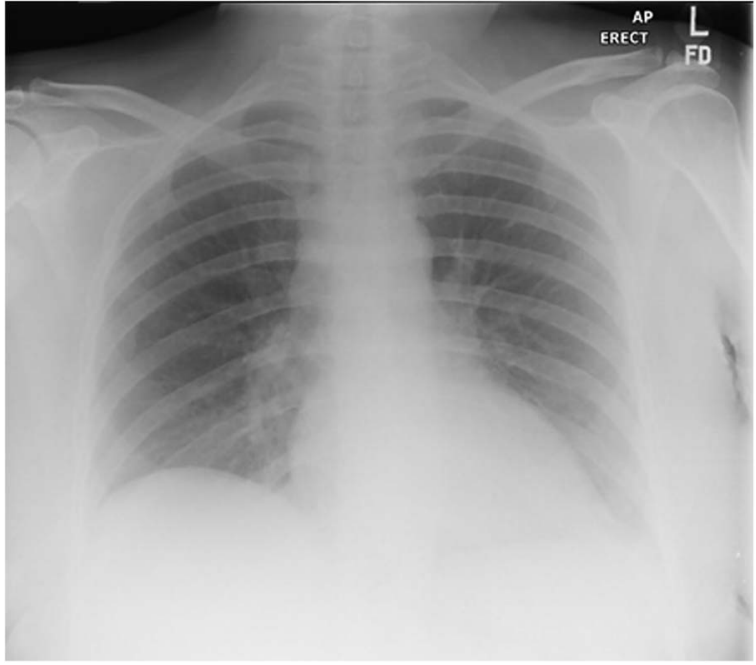

Figure 6 Erect chest radiograph demonstrating resolution of intraperitoneal free air.

imaging, ideally CT, are important in investigating and differentiating these complications. ${ }^{2}$

The management of duodenal perforation post-ERCP is controversial. Howard et $a l^{1}$ demonstrated successful conservative management in 36 of 40 patients with a perforation. The group suggests a risk stratification based on mechanism of injury, site of perforation and timing of diagnosis, to determine the need for operative intervention. Stapfer et $a l^{3}$ reviewed 14 cases of ERCP-related perforations and, in stable patients, concluded that conservative management was superior to surgical intervention. Operative management is patient-specific but often involves drainage of leaked contents, repair of duodenal defects and a cholecystectomy. ${ }^{3}$

\section{Learning points}

- Duodenal perforation is a rare $(0.6 \%)$ but important complication of endoscopic retrograde cholangiopancreatography (ERCP).

- Chest and abdominal radiographs are useful in assessing post-ERCP complications.

- In stable patients, conservative management of duodenal perforation post-ERCP is preferred.

Competing interests None declared.

Patient consent Obtained.

Provenance and peer review Not commissioned; externally peer reviewed.

\section{REFERENCES}

1 Howard TJ, Tan T, Lehman GA, et al. Classification and management of perforations complicating endoscopic sphincterotomy. Surgery 1999;126:658-65.

2 Loperfido S, Angelini G, Benedetti G, et al. Major early complications from diagnostic and therapeutic ERCP: a prospective multicenter study. Gastrointest Endosc 1998;48:1-10.

3 Stapfer M, Selby RR, Stain SC, et al. Management of duodenal perforation after endoscopic retrograde cholangiopancreatography and sphincterotomy. Ann Surg 2000;232:191-8 
Copyright 2015 BMJ Publishing Group. All rights reserved. For permission to reuse any of this content visit http://group.bmj.com/group/rights-licensing/permissions.

BMJ Case Report Fellows may re-use this article for personal use and teaching without any further permission.

Become a Fellow of BMJ Case Reports today and you can:

- Submit as many cases as you like

- Enjoy fast sympathetic peer review and rapid publication of accepted articles

- Access all the published articles

- Re-use any of the published material for personal use and teaching without further permission

For information on Institutional Fellowships contact consortiasales@bmjgroup.com

Visit casereports.bmj.com for more articles like this and to become a Fellow 